\title{
PENERAPAN ALGORITMA K-MEANS PADA SISWA BARU SEKOLAHMENENGAH KEJURUAN UNTUK CLUSTERING JURUSAN
}

\author{
Fauziah Nur ${ }^{1}$, Prof. M. Zarlis ${ }^{2}$, Dr. Benny Benyamin Nasution ${ }^{3}$ \\ Program Studi Magister Teknik Informatika, Universitas Sumatera Utara \\ Jl. Dr. T. Mansyur No. 9 Kampus USU Medan - 20155 \\ nur4ziah@gmail.com¹,m.zarlis@yahoo.com², bnasution@yahoo.com³
}

\begin{abstract}
Abstrak-Data mining merupakan teknik pengolahan data dalam jumlah besar untuk pengelompokan.Teknik ini digunakan dalam proses Knowledge Discovery in Database (KDD). Teknik tersebut mempunyai beberapa metode dalam pengelompokannya Nä̈ve-Bayes dan Nearest Neighbour, pohon keputusan (KD-Tree), ID3, K-Means, text mining dan dbscan. Dalam hal ini penulis mengelompokan data siswa baru sekolah menengah kejuruan tahun ajaran 2014/2015. Pengelompokan tersebut berdasarkan kriteria - kriteria data siswa. Pada penelitian ini, penulis menerapkan algoritma K-Means Clustering untuk pengelompokan data siswa baru sekolah menengah kejuruan. Dalam hal ini, pada umumnya untuk memamasuki jurusan hanya disesuaikan dengan nilai siswa saja namun dalam penelitian ini pengelompokan disesuaikan kriteria - kriteria siswa seperti penghasilan orang tua, tanggungan anak orang tua dan nilai tes siswa. Penulis menggunakan beberapa kriteria tersebut agar pengelompokan yang dihasilkan menjadi lebih optimal. Tujuan dari pengelompokan ini adalah terbentuknya kelompok jurusan pada siswa yang menggunakan algoritma K-Means clustering. Hasil dari pengelompokan tersebut diperoleh tiga kelompok yaitu kelompok tidak lulus, kelompok rekayasa perangkat lunak dan kelompok teknik komputer jaringan. Terdapat pusat cluster dengan Cluster-1=1.4;2.2;2.2, Cluster-2= 2.28;1.64;4 dan Cluster-3=5;2;6. Pusat cluster tersebut didapat dari beberapa iterasi sehingga mengahasilakan pusat cluster yang optimal.
\end{abstract}

Keywords-Kriteria, K-Means, Data Mining, Jurusan

\section{PENDAHULUAN}

Clustering merupakan salah satu metode data mining yang bersifat tanpa arahan (unsupervised) dan suatu metode untuk mencari dan mengelompokan data yang memiliki kemiripan karakteristik antara satu data dengan data lain[1]. Menurut kategori kekompakan, pengelompokan terbagi menjadi dua, yaitu komplet dan parsial. Jika semua data dapat bergabung menjadi satu, dapat dikatakan semua data kompak menjadi satu kelompok[2]. Pada clustering ini terdapat beberapa algoritma pengelompokan untuk mengelompokan data secara mudah. Salah satunya adalah algoritma $K$ Means yang merupakan metode analisis kelompok yang mengarah pada partisian $N$ objek pengamatan ke dalam $K$ kelompok, di mana setiap objek pengamatan sebuah kelompok data dengan mean (rata-rata) terdekat[2].

Pengelompokan pada umumnya diterapkan untuk mengelompokan dokumen atau benda yang tidak tersusun dengan rapi dan tidak sesuai sususannya pada tempatnya. Namun fungsi dari pengelompokan tidak hanya sekedar mengelompokan dokumen atau benda. Pengelompokan (clustering) dapat diterapkan dalam hal penentuan jurusan sekolah agar jurusan tersebut sesuai dengan kemampuan siswa.

Banyak lembaga pendidikan seperti sekolah menengah kejuruan yang hanya menggunakan nilai sebagai tolak ukur untuk memilih jurusan, sehingga pada akhirnya siswa menjadi salah mengambil jurusan dan tidak dapat menyesuaikan kemampuan yang siswa miliki dengan jurusan yang telah diambil. Dalam hal ini, untuk pengelompokan jurusan yang sesuai dengan kemampuan siswa adalah dapat ditentukan dengan data - data setiap siswa. Data yang dapat menjadi tolak ukur untuk pengelompokan jurusan yaitu nilai tes masuk sekolah menengah kejuruan, penghasilan orang tua, dan tanggungan anak orang tua. Dengan demikian pengelompokan jurusan yang diambil siswa akan lebih efektif bagi siswa itu sendiri.

Algoritma K-Means dalam hal ini akan mengelompokan data tersebut sesuai kriteria - kriteria yang dipilih dari data siswa.

\section{PENDAHULUAN}

\section{A. Data Mining}

Istilah data mining mulai dikenal sejak tahun 1990 , ketika pekerjaan pemanfaatan data menjadi sesuatu yang penting dalam berbagai bidang, mulai dari bidang akademik, bisnis hingga medis[2]. Munculnya data mining didasarkan pada jumlah data yang tersimpan dalam basis data semakin besar. Dalam berbagai literatur, teori-teori pada data mining sudah ada sejak lama seperti antara lain Naïve-Bayes dan Nearest Neighbour, Pohon Keputusan, aturan asosiasi, K-Means Clustering dan text mining[3]. 
Data mining disebut juga dengan knowledgediscovery in database (KDD) ataupun pattern recognition. Istilah $\mathrm{KDD}$ atau disebut penemuan pengetahuan data karena tujuan utama data mining adalah untuk memanfaatkan data dalam basis data dengan mengolahnya sehingga menghasilkan informasi baru yang berguna. Sedangkan istilah pattern recognition atau disebut pengenalan pola mempunyai tujuan pengetahuan yang akan digali dari dalam bongkahan data yang sedang dihadapi.

\section{B. Dasar Cluster}

Analisis kelompok (cluster analysis) adalah mengelompokkan data (objek) yang didasarkan hanya pada informasi yang ditemukan dalam data yang menggambarkan objek tersebut dan hubungan diantaranya[1]. Analisis Cluster sebagai metodologi untuk klasifikasi data secara otomatis menjadi beberapa kelompok dengan menggunakan ukuran asosiasi, sehingga data yang sama berada dalam satu kelompok yang sama dan data yang berbeda berada dalam kelompok data yang tidak sama.

Masukan (input) untuk sistem analisis cluster adalah seperangkat data dan kesamaan ukuran (atau perbedaan) antara dua data. Sedangkan keluaran (output) dari analisis cluster adalah sejumlah kelompok yang membentuk sebuah partisi atau struktur partisi dari kumpulan data. Salah satu hasil tambahan dari analisis cluster adalah deskripsi umum dari setiap cluster dan hal itu sangat penting untuk analisis lebih dalam dari karakteristik data set tersebut.

Ada saatnya di mana set data yang akan diproses dalam data mining belum diketahui label kelasnya. Pengelompokan data dilakukan dengan menggunakan algoritma yang sudah ditentukan dan selanjutnya data akan diproses oleh algoritma untuk dikelompokkan menurut karakteristik alaminya.

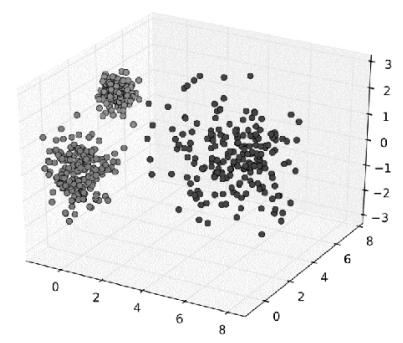

Gbr. 1 Pengelompokan dengan clustering

\section{Algoritma K-Means}

Algoritma K-Means merupakan algoritma pengelompokan iteratif yang melakukan partisi set data ke dalam sejumlah $K$ cluster yang sudah ditetapkan di awal. Algoritam K-Means sederhana untuk diimplementasikan dan dijalankan, relatif cepat, mudah beradaptasi, umum penggunaannya dalam praktek[2]. K-Means dapat diterapkan pada data yang direpresentasikan dalam $\mathrm{r}$-dimensi ruang tempat. $K$ means mengelompokan set data r-dimensi, $\mathrm{X}=$ $\left\{x_{i} \mid i=1, \ldots, \mathrm{N}\right\}$. Algoritma K-Means mengelompokan semua titik data dalam $X$ sehingga setiap titik $x_{i}$ hanya jatuh dalam satu $K$ partisi[4].

Tujuan pengelompokan ini adalah untuk meminimalkan fungsi objek yang diset dalam proses pengelompokan, yang pada umumnya berusaha meminimalkan variasi di dalam suatu kelompok dan memaksimalkan variasi antarkelompok. Parameter yang hrsus dimasukkan ketika menggunakan algoritma $K$-Means adalah nilai $K$. Nilai $K$ yang digunkan pada umumnya didasarkan pada informasi yang diketahui sebelumnya mengenai sebenarnya berapa banyak cluster yang muncul dalam $X$, berapa banyak yang digunakan untuk penerapnnya, atau jenis cluster dicari dengan melakukan percobaan dengan beberapa nilai $K$. Set representatif cluster dinyatakan $\mathrm{C}=\left\{c_{j} \mid j=1, \ldots, \mathrm{K}\right\}$. sejumlah $K$ representatif cluster tersebut sebagai cluster centroid (titik pusat cluster). Untuk set data dalam $X$ dikelompokan berdasarkan konsep kedekatan atau kemiripan, namun kuantitas yang digunkan untuk mengukurnya adalah ketidakmiripan. Metrik yang umum digunakan untuk ketidakmiripan tersebut adalah Euclidean.

Secara umum algoritma K-Means memiliki langkah-langkah dalam pengelompokan, diantaranya:

1) Inisilisasi: menentukan nilai $K$ centroid yang diinginkan dan metrik ketidakmiripan (jarak) yang diinginkan.

2) Memilih $K$ data dari set $X$ sebagai centroid. Untuk menentukan centroid dapat menggunakan persamaan (1).

Jumlahdata

Jumlah olasst1

3) Mengalokasikan semua data ke centroid terdekat dengan metrik jarak yang telah ditetapkan.

4) Menghitung kembali centroid $C$ berdasarkan data yang mengikuti cluster masing - masing.

5) Mengulangi langkah 3 dan 4 hingga kondisi konvergen tercapai.

Berikut ini adalah rumus untuk menentukan jumlah cluster:

$$
K=\sqrt{\frac{N}{2}}
$$

Keterangan:

$$
\begin{array}{ll}
\mathrm{K} & =\text { klaster } \\
\mathrm{N} & =\text { jumlah data }
\end{array}
$$

Menghitung jarak pada ruang jarak Euclidean menggunakan formula:

$$
D\left(x_{2} x_{1}\right)=\left\|x_{2}-x_{1}\right\|_{2}=\sqrt{\sum_{j=1}^{p}\left|x_{2 j}-x_{1 j}\right|^{2}}
$$

Keterangan:

$$
\begin{array}{ll}
D & =\text { euclidean distance } \\
x & =\text { banyaknya objek } \\
\Sigma^{\mathrm{p}} & =\text { jumlah data } \text { record }
\end{array}
$$




\section{HASIL DAN PEMBAHASAN}

Penelitian ini bertujuan untuk mengelompokan data siswa baru sekolah menengah kejuruan dengan menggunakan algoritma K-Means. Agar tercapai tujuan tersebut, penulis akan melakukan pengujian dengan menggunakan data pada salah satu sekolah menengah kejuruan di medan yaitu SMK swasta medan area-1 tahun ajaran 2014/2015.

Adapun pengelompokan tersebut menggunakan langkah - langkah sebagai berikut:

\section{A. Sumber Data}

Dalam penelitian ini, sumber data diambil dari smk swasta medan area-1dimana data tersebut merupakan data siswa baru tahun ajaran 2014/2015.

TABEL I

DATA SISWA BARU

\begin{tabular}{|c|c|c|c|c|c|c|c|c|c|}
\hline No. & $\begin{array}{c}\text { Mo. } \\
\text { Registros }\end{array}$ & Hom & Tagged labir & 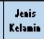 & Alame & 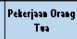 & 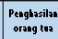 & 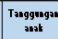 & Nitiz ites \\
\hline 1 & D320 & Áman Eunadi & 23-08-1998 & L & Jn. Pinang Earis Gay, Bersama & Wirswussa & 1750000 & 2 & 80 \\
\hline 2 & 0321 & Desi Wulundan & $04-12-1999$ & $\mathrm{P}$ & Jn. Birabikmt1 & Wirasumsia & 3000000 & 3 & 75 \\
\hline 3 & 0322 & Dita Fizk Parabri & $25-12-1999$ & $\mathrm{P}$ & Ju.Masidi Gg: Fithadi & Sales & 2000000 & 1 & 90 \\
\hline 4 & 0323 & Fanizal & $29-99-1999$ & $\mathrm{~L}$ & In.Segoia G9, Berana & Wirzsususa & 2500000 & 1 & 85 \\
\hline 5 & 0324 & Hesisando & $24-144-2000$ & $\mathrm{~L}$ & Jn.Masickmi2 & Gun & 2500000 & 2 & 70 \\
\hline 6 & 0325 & Jesika Ramadani & 02-01-1999 & $\mathrm{P}$ & \begin{tabular}{|l|l|} 
In. PunggukN No. 30 \\
\end{tabular} & Wirswusta & 2800000 & 2 & 75 \\
\hline 7 & 0326 & M.AbsuMubrazak & $09-12-1999$ & L & Jn. Etasin Traurg Gusta No. $8 \mathrm{~B}$ & Wirususta & 3500000 & 2 & 70 \\
\hline 8 & 0327 & Muhsenmad Gippas & (68-84-1999 & $\mathrm{L}$ & In. Seia Makmur Surggast Kanan & Kuileangunan & 1500000 & 3 & 65 \\
\hline 9 & 0328 & M. Finsaldy $A .5$ & 7-1-44-2000 & $\mathrm{L}$ & In Konpes Gg. Asamm & Mirasumsasa & 1800000 & 2 & 85 \\
\hline 10 & 0329 & M. FikikykKhalid & $25-06-1999$ & $\mathrm{~L}$ & $\begin{array}{l}\text { Jn. Geatik N2. 8. Medan Sungagal } \\
\end{array}$ & Wirswswası & 1700000 & 2 & 80 \\
\hline 11 & 0330 & 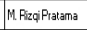 & $60-77-1999$ & L & 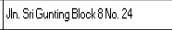 & PN5 & 5000000 & 2 & 95 \\
\hline 12 & 0331 & M. S.idikKadafi & (64-06-1999 & $\mathrm{L}$ & Jn.Gsudad No. 66 & Wirswassa & 870000 & 2 & 60 \\
\hline 13 & 0332 & Maisa Si Fahayu & {$[2-99-1999$} & P & In. Pirangag Earis Cyy Beersana & PNS & 4500000 & 1 & T0 \\
\hline 14 & 0333 & Ndfizal & 25-10-1998 & $L$ & 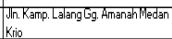 & Supin & 3000000 & 1 & 85 \\
\hline 15 & 0334 & Mugie Fimadhan & 10-2-12-1999 & $L$ & 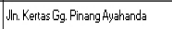 & Wirswasta & 2000000 & 1 & 75 \\
\hline 16 & 0335 & Mussuwend & 10-12-1999 & $L$ & $\begin{array}{ll}\text { Jn. Gauda No. } 76 \mathrm{C} \\
\end{array}$ & \begin{tabular}{|l|} 
Wirswussa \\
\end{tabular} & 1800000 & 2 & 70 \\
\hline 17 & 0336 & Prif Syahpurti & $66-07-1999$ & $\mathrm{P}$ & In. Beingin & Wirswusta & 1500000 & 2 & 80 \\
\hline 18 & 0337 & RindkFFivignto & 8--08-1999 & $\mathrm{L}$ & In. Gspeta_KIIIINo. $215 \mathrm{AA}$ & Wirswassa & 900000 & 2 & 85 \\
\hline 19 & 0338 & Rezzuddin & B--08-1999 & L & Komplek PLNP צys Sai & Wirasumsia & 950000 & 1 & 85 \\
\hline 20 & D339 & Rienaldi Pane & $27-11-1999$ & $L$ & Jn. Basi Desa Gg, wakad & Eurch & 25000000 & 2 & 65 \\
\hline
\end{tabular}

\section{B. Pengolahan Data}

Sebelum data siswa baru tersebut dikelompokan ke dalam jurusan yang sesuai kriteria. Data mentah tersebut akan ditransformasi dengan cara menginisialisasi data ke dalam bentuk angka yang dapat diolah dalam pengelompokan.

TABEL II

RANGE PENGELOMPOKAN JURUSAN

\begin{tabular}{|c|c|c|l|}
\hline Cluster & $\Sigma \min$ & $\Sigma \max$ & \multicolumn{1}{|c|}{ cluster } \\
\hline 1 & 0 & 7 & Tidak Lulus \\
\hline 2 & 8 & 11 & Rekayasa Perangkat Lunak (RPL) \\
\hline 3 & 12 & 15 & Teknik Komputer Jaringan (TK) \\
\hline 4 & 16 & 18 & Administrasi Perkantoran (AP) \\
\hline 5 & 19 & 20 & Akuntansi (AK) \\
\hline 6 & 21 & 22 & Multimedia (MM) \\
\hline
\end{tabular}

Berdasarkan range yang telah ditentukan pada pengelompokan jurusan, maka dapat disimpulkan bahwa pengelompokan data siswa baru ke dalam jurusan tanpa menggunakan metode.

Pada data tersebut, tidak semua kriteria yang dapat menjadi patokan. Dalam hal ini, kriteria yang diinisialisasikan adalah penghasilan orang tua menjadi
$\mathrm{X} 1$, Tanggungan anak diubah menjadi $\mathrm{X} 2$, dan hasil nilai tes diubah menjadi X3.

TABEL III

HASIL INISIALISASI DATA

\begin{tabular}{|c|c|c|c|c|c|}
\hline $\begin{array}{c}\text { Ho. } \\
\text { pendaftara }\end{array}$ & $\mathbf{x} \mathbf{1}$ & $\mathbf{x} \mathbf{2}$ & $\mathbf{x 3}$ & Junlat & Cluster \\
\hline $\mathrm{D} 320$ & 1 & 2 & 4 & 7 & 1 \\
\hline $\mathrm{D} 321$ & 3 & 3 & 3 & 9 & 2 \\
\hline $\mathrm{D} 322$ & 2 & 1 & 6 & 9 & 2 \\
\hline $\mathrm{D} 323$ & 2 & 1 & 5 & 8 & 2 \\
\hline $\mathrm{D} 324$ & 2 & 2 & 2 & 6 & 1 \\
\hline $\mathrm{D} 325$ & 3 & 2 & 3 & 8 & 2 \\
\hline $\mathrm{D} 326$ & 4 & 2 & 2 & 8 & 2 \\
\hline $\mathrm{D} 327$ & 1 & 3 & 1 & 5 & 1 \\
\hline $\mathrm{D} 328$ & 2 & 2 & 5 & 9 & 2 \\
\hline $\mathrm{D} 329$ & 2 & 2 & 4 & 8 & 2 \\
\hline $\mathrm{D} 330$ & 5 & 2 & 6 & 13 & 3 \\
\hline $\mathrm{D} 331$ & 1 & 2 & 1 & 4 & 1 \\
\hline $\mathrm{D} 332$ & 5 & 1 & 2 & 8 & 2 \\
\hline $\mathrm{D} 333$ & 3 & 1 & 5 & 9 & 2 \\
\hline $\mathrm{D} 334$ & 2 & 1 & 3 & 6 & 1 \\
\hline $\mathrm{D} 335$ & 1 & 2 & 2 & 5 & 1 \\
\hline $\mathrm{D} 336$ & 1 & 2 & 4 & 7 & 1 \\
\hline $\mathrm{D} 337$ & 1 & 2 & 5 & 8 & 2 \\
\hline $\mathrm{D} 338$ & 1 & 1 & 5 & 7 & 1 \\
\hline $\mathrm{D} 339$ & 2 & 2 & 1 & 5 & 1 \\
\hline
\end{tabular}

\section{Proses Data}

Setelah data diolah, maka langkah selanjutnya adalah data diproses untuk membentuk pengelompokan data ke dalam jurusan sesuai kriteria yang telah ditentukan. Data yang telah ditransformasi tersebut akan diproses dengan menggunakan sebuah algoritma pengelompokan (cluster) yaitu algoritma $K$ means. Berikut ini adalah sebuah flowchart dalam pengelompokan jurusan pada siswa baru sekolah menengah kejuruan. 


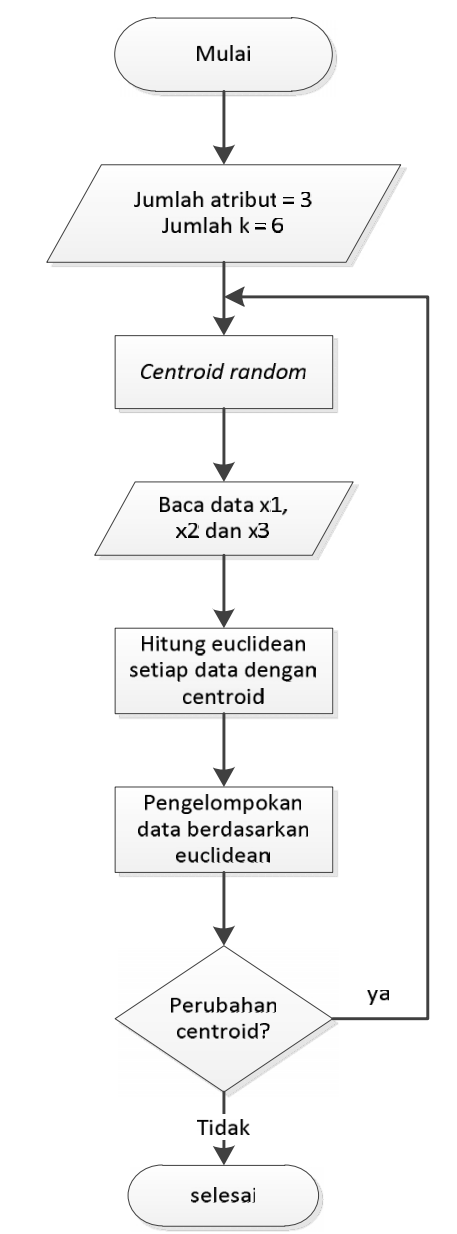

Gbr. 2 Flowchart Pengclusteran K-Means

Pada tahapan ini yaitu menentukan centroid $K$ means dari data siswa baru sekolah menengah kejuruan tahun ajaran 2014/2015. Dalam menentukan target $K$-means tersebut bertujuan untuk mendapatkan target data atau jarak kelompok yaitu titik pusat (centroid) kelompok awal untuk menghitung algoritma K-means.

Pada tabel 4 merupakan hasil perhitungan $K$-means untuk data sampel siswa baru tahun ajaran 2014/2015 pada sekolah menengah kejuruan medan area-1 yang berdasarkan kriteria - kriteria yang telah ditentukan untuk setiap kelompok (cluster).

Dalam hal ini, pengelompokan yang terbentuk terjadi sebanyak 3 kelompok (cluster). Untuk perhitungan secara lengkap terdapat pada tabel - tabel berikut:
TABEL IV

TARGET K-MEANS DATA SAMPEL SISWA BARU SMK UNTUK C1

\begin{tabular}{|c|c|c|c|}
\hline $\begin{array}{c}\text { Mo. } \\
\text { Pendaftara. }\end{array}$ & $x 1$ & $x 2$ & X3 \\
\hline D320 & 1 & 2 & 4 \\
\hline D324 & 2 & 2 & 2 \\
\hline $\mathrm{Q} 327$ & 1 & 3 & 1 \\
\hline D331 & 1 & 2 & 1 \\
\hline D334 & 2 & 1 & 3 \\
\hline D335 & 1 & 2 & 2 \\
\hline D336 & 1 & 2 & 4 \\
\hline D338 & 1 & 1 & 5 \\
\hline Q339 & 2 & 2 & 1 \\
\hline CLUSTER 1 & 1.33333 & 1.88889 & 2.55556 \\
\hline
\end{tabular}

Setelah pengelompokan untuk kelompok pertama (cluster-1) telah terkelompok. Maka dapat dilakukan untuk pengelompokan data kelompok kedua (cluster2).

TABEL V

TARGET $K$-MEANS DATA SAMPEL SISWA BARU SMK UNTUK C2

\begin{tabular}{|c|c|c|c|}
\hline \begin{tabular}{|c|} 
No. \\
Pendaftaraः \\
\end{tabular} & $x 1$ & $x 2$ & x3 \\
\hline D321 & 3 & 3 & 3 \\
\hline 0322 & 2 & 1 & 6 \\
\hline D323 & 2 & 1 & 5 \\
\hline D325 & 3 & 2 & 3 \\
\hline 0326 & 4 & 2 & 2 \\
\hline 0328 & 2 & 2 & 5 \\
\hline 0329 & 2 & 2 & 4 \\
\hline 0332 & 5 & 1 & 2 \\
\hline D333 & 3 & 1 & 5 \\
\hline D337 & 1 & 2 & 5 \\
\hline CLUSTER 2 & 2.7 & 1.7 & 4 \\
\hline
\end{tabular}

Data yang dikelompokan lainnya akan masuk pada kelompok 3 (cluster 3 ) yaitu hanya terdapat satu record data pada kelompok 3 .

TABEL VI

TARGET $K$-MEANS DATA SAMPEL SISWA BARU SMK UNTUK C3

\begin{tabular}{|c|c|c|c|}
\hline \begin{tabular}{|c|c} 
Ho. \\
Peadaftarar \\
\end{tabular} & X1 & $\mathrm{x} 2$ & $\mathrm{X} 3$ \\
\hline D330 & 5 & 2 & 6 \\
\hline CLUSTER 3 & 5 & 2 & 6 \\
\hline
\end{tabular}


setelah semua data telah terkelompok, maka untuk menentukan titik pusat pada cluster dapat diambil nilai rata - rata dari setiap cluster.

Adapun tahapan proses algoritma K-means adalah sebagai berikut:

1. Menentukan nilai $k$ dari jumlah cluster yang akan dibentuk. Pada tahapan ini cluster yang terbentuk sebanyak 3 cluster.

2. Menentukan titik pusat (centroid) awal dari setiap cluster. Dalam penelitian ini titik pusat awal ditentukan dengan menggunakan range dari jurusan.

TABEL VII

CENTROID AWAL CLUSTER

\begin{tabular}{|c|c|c|c|}
\hline \multicolumn{1}{|c|}{ CENTROID AWAL CLUSTER } \\
\hline CLUSTER & \multicolumn{1}{c|}{$\mathbf{x} 1$} & \multicolumn{1}{c|}{$\mathbf{X 2}$} & \multicolumn{1}{c|}{$\mathbf{x 3}$} \\
\hline C1 & $\mathbf{1 . 3 3 3 3 3}$ & $\mathbf{1 . 8 8 8 8 9}$ & $\mathbf{2 . 5 5 5 5 6}$ \\
\hline C2 & $\mathbf{2 . 7}$ & $\mathbf{1 . 7}$ & 4 \\
\hline C3 & $\mathbf{5}$ & $\mathbf{2}$ & 6 \\
\hline
\end{tabular}

3. Setelah titik pusat cluster ditentukan, maka tahap selanjutnya adalah menghitung jarak terdekat atau euclidean dengan menggunakan persamaan 3, yaitu menghitung jarak dari data siswa baru pertama ke titik pusat cluster.

$$
\mathrm{D}(1,1)=\sqrt{(1-1.33)^{2}+(2-1.88)^{2}+(4-2.55)^{2}}=1.48657
$$

Dari hasil perhitungan di atas didapatkan bahwa jarak terdekat bernilai 1.48657. Selanjutnya perhitungan jarak data pertama untuk cluster kedua.

$$
D(1,2)=\sqrt{(1-2.7)^{2}+(2-1.7)^{2}+(4-4)^{2}}=1.72627
$$

Dari hasil perhitungan tersebut didapatkan jarak terdekat bernilai 1.72627 . Kemudian perhitungan jarak data pertama untuk cluster ketiga.

$$
\mathrm{D}(1,3)=\sqrt{(1-5)^{2}+(2-2)^{2}+(4-6)^{2}}=4.47214
$$

Dari hasil perhitungan tersebut didapatkan jarak terdekat bernilai 4.47214. Berdasarkan perhitungan euclidean untuk data pertama diperoleh jarak terdekat cluster adalah 1.48657 yang terkelompok pada cluster kesatu (C1) dan untuk

\begin{tabular}{|c|c|c|c|c|c|c|c|}
\hline \multirow{2}{*}{$\begin{array}{c}\text { No } \\
\text { Pendafta } \\
\text { ran }\end{array}$} & \multicolumn{3}{|c|}{ Kriteria } & \multicolumn{3}{|c|}{ Cluster } & \multirow{2}{*}{\begin{tabular}{|c|} 
Jarak \\
Terdekat \\
Ke Cluster
\end{tabular}} \\
\hline & x1 & $\mathrm{x} 2$ & x3 & C1 & C2 & C3 & \\
\hline D320 & 1 & 2 & 4 & 1.48657 & 1.72627 & 4.47214 & 1 \\
\hline D321 & 3 & 3 & 3 & 2.0518 & 1.66733 & 3.74166 & 2 \\
\hline D322 & 2 & 1 & 6 & 3.61922 & 2.23159 & 3.16228 & 2 \\
\hline $\mathrm{D} 323$ & 2 & 1 & 5 & 2.68512 & 1.40712 & 3.31662 & 2 \\
\hline D324 & 2 & 2 & 2 & 0.87489 & 2.14009 & 5 & 1 \\
\hline D325 & 3 & 2 & 3 & 1.72848 & 1.08628 & 3.60555 & 2 \\
\hline D326 & 4 & 2 & 2 & 2.72619 & 2.40416 & 4.12311 & 2 \\
\hline D327 & 1 & 3 & 1 & 1.94047 & 3.68511 & 6.48074 & 1 \\
\hline D328 & 2 & 2 & 5 & 2.53616 & 1.25698 & 3.16228 & 2 \\
\hline D329 & 2 & 2 & 4 & 1.59474 & 0.76158 & 3.60555 & 2 \\
\hline $\mathrm{D} 330$ & 5 & 2 & 6 & 5.032 & 3.06268 & 0 & 3 \\
\hline D331 & 1 & 2 & 1 & 1.59474 & 3.46121 & 6.40312 & 1 \\
\hline $\mathrm{D} 332$ & 5 & 1 & 2 & 3.81356 & 3.1273 & 4.12311 & 2 \\
\hline D333 & 3 & 1 & 5 & 3.08921 & 1.25698 & 2.44949 & 2 \\
\hline D334 & 2 & 1 & 3 & 1.1967 & 1.40712 & 4.3589 & 1 \\
\hline $\mathrm{D} 335$ & 1 & 2 & 2 & 0.65734 & 2.64197 & 5.65685 & 1 \\
\hline $\mathrm{D} 336$ & 1 & 2 & 4 & 1.48657 & 1.72627 & 4.47214 & 1 \\
\hline D337 & 1 & 2 & 5 & 2.46957 & 1.99499 & 4.12311 & 2 \\
\hline D338 & 1 & 1 & 5 & 2.62232 & 2.09284 & 4.24264 & 2 \\
\hline D339 & 2 & 2 & 1 & 1.69604 & 3.09516 & 5.83095 & 1 \\
\hline
\end{tabular}

TABEL VIII

PERHITUNGAN EUCLIDEAN ITERASI-1

Setelah data dikelompokan pada iterasi pertama, maka langkah selanjutnya adalah membentuk titik pusat baru dengan menentukan nilai rata - rata dari setiap data yang sudak memebentuk cluster untuk melanjutkan perhitungan jarak terdekat iterasi kedua dan akan menunjukkan cluster yang terbentuk selanjutnya dapat membentuk cluster yang konvergen.

TABEL IX CENTROID BARU PERTAMA

\begin{tabular}{|c|c|c|c|}
\hline CLUSTER & X1 & X2 & X3 \\
\hline C1 & 1.375 & 2 & 2.25 \\
\hline C2 & 2.54545 & 1.63636 & 4.09091 \\
\hline C3 & 5 & 2 & 6 \\
\hline
\end{tabular}

Jika cluster belum konvergen, maka centroid akan dibangkitkan kembali dan menghitung kembali euclidean dari setiap data siswa. Langkah perhitungan jarak terdekat seperti langkah ketiga sebelumnya. Berikut perhirtungan jarak terdekat untuk data kedua. $\mathrm{D}(2,1)=\sqrt{(3-1.33)^{2}+(3-1.88)^{2}+(3-2.55)^{2}}=2.0518$ Dari hasil perhitungan tersebut didapatkan jarak terdekat bernilai 2.0518 .

Untuk perhitungan euclidean dapat dilihat secara lengkap pada tabel di bawah ini. 
TABEL X PERHITUNGAN EUCLIDEAN ITERASI-2

\begin{tabular}{|c|c|c|c|c|c|c|c|}
\hline \multirow{2}{*}{$\begin{array}{l}\text { No } \\
\text { Pendaft } \\
\text { aran }\end{array}$} & \multicolumn{3}{|c|}{ Kriteria } & \multicolumn{3}{|c|}{ Cluster } & \multirow{2}{*}{$\begin{array}{c}\text { Jarak } \\
\text { Terdekat } \\
\text { Ke Cluster }\end{array}$} \\
\hline & $\mathrm{X} 1$ & $\mathrm{x} 2$ & $\mathrm{X} 3$ & $\mathrm{Cl}$ & $\mathrm{C} 2$ & C3 & \\
\hline & 1 & 2 & 4 & 1.78973 & 1.59026 & 4.47214 & 2 \\
\hline $\mathrm{D} 321$ & 3 & 3 & 3 & 2.05015 & 1.80449 & 3.74166 & 2 \\
\hline D322 & 2 & 1 & 6 & 3.93105 & 2.08497 & 3.16228 & 2 \\
\hline $\mathrm{D} 323$ & 2 & 1 & 5 & 2.99218 & 1.2365 & 3.31662 & 2 \\
\hline $\mathrm{D} 324$ & 2 & 2 & 2 & 0.67315 & 2.19127 & 5 & 1 \\
\hline $\mathrm{D} 325$ & 3 & 2 & 3 & 1.78973 & 1.2365 & 3.60555 & 2 \\
\hline $\mathrm{D} 326$ & 4 & 2 & 2 & 2.63688 & 2.5729 & 4.12311 & 2 \\
\hline $\mathrm{D} 327$ & 1 & 3 & 1 & 1.64412 & 3.71506 & 6.48074 & 1 \\
\hline $\mathrm{D} 328$ & 2 & 2 & 5 & 2.82013 & 1.1208 & 3.16228 & 2 \\
\hline $\mathrm{D} 329$ & 2 & 2 & 4 & 1.85826 & 0.66183 & 3.60555 & 2 \\
\hline $\mathrm{D} 330$ & 5 & 2 & 6 & 5.21566 & 3.13076 & 0 & 3 \\
\hline $\mathrm{D} 331$ & 1 & 2 & 1 & 1.30504 & 3.47482 & 6.40312 & 1 \\
\hline $\mathrm{D} 332$ & 5 & 1 & 2 & 3.7687 & 3.28659 & 4.12311 & 2 \\
\hline $\mathrm{D} 333$ & 3 & 1 & 5 & 3.34711 & 1.19917 & 2.44949 & 2 \\
\hline $\mathrm{D} 334$ & 2 & 1 & 3 & 1.39754 & 1.3757 & 4.3589 & 2 \\
\hline $\mathrm{D} 335$ & 1 & 2 & 2 & 0.45069 & 2.62537 & 5.65685 & 1 \\
\hline $\mathrm{D} 336$ & 1 & 2 & 4 & 1.78973 & 1.59026 & 4.47214 & 2 \\
\hline $\mathrm{D} 337$ & 1 & 2 & 5 & 2.77545 & 1.82951 & 4.12311 & 2 \\
\hline $\mathrm{D} 338$ & 1 & 1 & 5 & 2.95011 & 1.90259 & 4.24264 & 2 \\
\hline D339 & 2 & 2 & 1 & 1.39754 & 3.15966 & 5.83095 & 1 \\
\hline
\end{tabular}

Pada perhitungan jarak terdekat di atas centroid baru yang dibangkitkan ternyata belum konvergen, sehingga iterasi harus dilanjutkan. Dalam penelitian ini, iterasi clustering data siswa terjadi sebanyak 3 kali iterasi. Pada pengelompokan data di atas didapat titik cluster baru dengan nilai sebagai berikut:

TABEL XI

CENTROID BARU KEDUA

\begin{tabular}{|c|c|c|c|}
\hline CLUSTER & $\mathrm{X} 1$ & $\mathrm{X} 2$ & $\mathrm{X} 3$ \\
\hline $\mathrm{C} 1$ & 1.4 & 2.2 & 1.4 \\
\hline $\mathrm{C} 2$ & 2.285714 & 1.6428571 & 4 \\
\hline $\mathrm{C} 3$ & 5 & 2 & 6 \\
\hline
\end{tabular}

Centroid baru kedua yang dibangkitkan ternyata sudah konvergen, sehingga perhitungan jarak terdekat clustering berhenti pada iterasi-3. Adapun perhitungan secara lengkapnya sebagai berikut:

TABEL XII

PERHITUNGAN EUCLIDEAN ITERASI-3

\begin{tabular}{|c|c|c|c|c|c|c|c|}
\hline \multirow{2}{*}{$\begin{array}{c}\text { No } \\
\text { Pendaftar } \\
\text { an }\end{array}$} & \multicolumn{3}{|c|}{ Kriteria } & \multicolumn{3}{|c|}{ Cluster } & \multirow{2}{*}{$\begin{array}{c}\text { Jarak Terdek at } \\
\text { Ke Cluster }\end{array}$} \\
\hline & $\mathrm{X} 1$ & $\mathrm{x} 2$ & $x 3$ & C1 & C2 & C3 & \\
\hline $\mathrm{D} 320$ & 1 & 2 & 4 & 2.638181 & 1.334396 & 4.47 & 2 \\
\hline D321 & 3 & 3 & 3 & 2.4 & 1.830858 & 3.74 & 2 \\
\hline $\mathrm{D} 322$ & 2 & 1 & 6 & 4.791659 & 2.120117 & 3.16 & 2 \\
\hline $\mathrm{D} 323$ & 2 & 1 & 5 & 3.841875 & 1.22266 & 3.32 & 2 \\
\hline $\mathrm{D} 324$ & 2 & 2 & 2 & 0.87178 & 2.05163 & 5 & 1 \\
\hline $\mathrm{D} 325$ & 3 & 2 & 3 & 2.271563 & 1.279748 & 3.61 & 2 \\
\hline $\mathrm{D} 326$ & 4 & 2 & 2 & 2.675818 & 2.658256 & 4.12 & 2 \\
\hline $\mathrm{D} 327$ & 1 & 3 & 1 & 0.979796 & 3.534812 & 6.48 & 1 \\
\hline $\mathrm{D} 328$ & 2 & 2 & 5 & 3.655133 & 1.099629 & 3.16 & 2 \\
\hline $\mathrm{D} 329$ & 2 & 2 & 4 & 2.675818 & 0.457366 & 3.61 & 2 \\
\hline $\mathrm{D} 330$ & 5 & 2 & 6 & 5.844656 & 3.390413 & 0 & 3 \\
\hline $\mathrm{D} 331$ & 1 & 2 & 1 & 0.6 & 3.283384 & 6.4 & 1 \\
\hline D332 & 5 & 1 & 2 & 3.841875 & 3.43229 & 4.12 & 2 \\
\hline $\mathrm{D} 333$ & 3 & 1 & 5 & 4.118252 & 1.386892 & 2.45 & 2 \\
\hline $\mathrm{D} 334$ & 2 & 1 & 3 & 2.088061 & 1.22266 & 4.36 & 2 \\
\hline $\mathrm{D} 335$ & 1 & 2 & 2 & 0.748331 & 2.40429 & 5.66 & 1 \\
\hline $\mathrm{D} 336$ & 1 & 2 & 4 & 2.638181 & 1.334396 & 4.47 & 2 \\
\hline $\mathrm{D} 337$ & 1 & 2 & 5 & 3.627671 & 1.667517 & 4.12 & 2 \\
\hline $\mathrm{D} 338$ & 1 & 1 & 5 & 3.815757 & 1.751093 & 4.24 & 2 \\
\hline D339 & 2 & 2 & 1 & 0.748331 & 4 & 5.83 & 1 \\
\hline
\end{tabular}

Pada iterasi-3 tersebut, titik pusat dari setiap cluster sudah tidak berubah dan tidak ada lagi terdapat data yang berpindah dari satu cluster ke cluster yang lain. Maka dari itu, data siswa baru SMK telah terkelompok sesuai kriteria yang ditentukan untuk memasuki jurusan pada sekolah menengah kejuruan menggunakan algoritma $K$-Means.

\section{KESIMPULAN}

Dari hasil penelitian yang telah dilakukan, maka penulis dapat menarik beberapa kesimpulan, diantaranya sebagai berikut:

1. Pengujian yang dilakukan dalam penelitian ini, iterasi clustering pada data siswa baru SMK terjadi sebanyak 3 kali iterasi.

2. Berdasarkan hasil cluster dengan menerapkan beberapa kriteria dari calon siswa menggunakan $K$-Means dapat diambil pengelompokan dengan rata - rata jurusan yang diambil adalah rekayasa perangkat lunak dan sedikit jumlah siswa yang tidak lulus. Bahkan ada beberapa jurusan yang tidak dibuka dikarenakan kriteria - kriteria siswa tidak dapat lulus dalam jurusan tersebut.

\section{REFERENCE}

[1] Y. Agusta, "K-Means Penerapan, Permasalahan dan Metode Terkait," Jurnal Sistem dan Informatika, vol. 3, pp. 47-60, Pebruari 2007.

[2] M. Kantardzic, J. Wiley and Sons, Data Mining: Concepts, Models, methods, and Algorithms, 2003

[3] N. P. E. Merliana, Ernawati and A. J. Santoso, "Penentuan Jumlah Cluster Terbaik Pada Metode KMeans Clustering," SENDI U.

[4] Mardiani, "Perbandingan Algoritma K-Means dan EM untuk Clusterisasi Nilai Mahasiswa Berdasarkan Asal Sekolah," Citec Journal, vol. 1, no. 4, pp. 316-325, Agustus-Oktober 2014. 